Pak. j. sci. ind. res. ser. A: phys. sci. 2017 60(1) 42-49

\title{
Sulphide Removal from Sewage Wastewater by Oxidation Technique
}

\author{
Muhammad Tahir Butt*, Naz Imtiaz, Naeem Abbas and Rauf Ahmad Khan \\ CEPS, PCSIR Laboratories Complex, Ferozepur Road Lahore-54600, Pakistan
}

(received August 19, 2015; revised March 31, 2016; accepted April 08, 2016)

\begin{abstract}
In this study sewage wastewater samples were collected from different areas of Lahore, Pakistan from the WASA sewer system and then different chemical oxidizers: $\mathrm{O}_{2}, \mathrm{KMNO}_{4}, \mathrm{H}_{2} \mathrm{O}_{2}$ were used to remove the sulphides from these samples for selection of suitable oxidizer for treatment. From these results, it was observed that $\mathrm{H}_{2} \mathrm{O}_{2}$ was found effective and suitable for treatment and it can be used for this purpose. Theoretical and experimental doses required for treatment were similar. The $\mathrm{KMNO}_{4}$ oxidation reactions were completed in five minutes time while $\mathrm{H}_{2} \mathrm{O}_{2}$ required more time and removed sulphide completely with slow chemical reaction. Different doses of oxidizer such as 1 to $6 \mathrm{~g}$ of oxygen, 1 to $14 \mathrm{~g}$ of $\mathrm{KMNO}_{4}, 1$ to $11 \mathrm{~g}$ of $\mathrm{H}_{2} \mathrm{O}_{2}$ with different ratios were used and $\mathrm{H}_{2} \mathrm{O}_{2}$ was found suitable. Using $11 \mathrm{~g}$ of $\mathrm{H}_{2} \mathrm{O}_{2}$ dose, $100 \%$ sulphides were removed, $\mathrm{H}_{2} \mathrm{O}_{2}$ as an oxidizer was found more suitable for sulphide removal from wastewater.
\end{abstract}

Keywords: treatment, sulphide removal, wastewater, oxidation technique

\section{Introduction}

Wastewater treatment is a major challenge to the industrial advancements and treatment of the wastewater in efficient way has also become very vital problem. The organic and inorganic pollutants in the liquid wastes can be treated by various techniques like activated sludge process, membrane separation and adsorption (Sunil and Jayant, 2014). In case of contaminants like $\mathrm{H}_{2} \mathrm{~S}$ vapours, chemical treatments, adsorption, oxidation, bio-filtration. and membrane technology can be used for treatment. The pollutants in the wastewater include hydrogen sulphide, sulphur dioxide, carbon dioxide, and carbon monoxide.

Maata et al. (2005) used aqueous metal sulphate as absorbent for hydrogen sulphide $\left(\mathrm{H}_{2} \mathrm{~S}\right)$ removal. Premkumar and Krishnamohan (2013) also used bio filters for removal of $\mathrm{H}_{2} \mathrm{~S}$ from the wastewater stream. $\mathrm{H}_{2} \mathrm{~S}$ generation in wastewater streams depend on the temperature and $\mathrm{pH}$ of wastewater.

$\mathrm{H}_{2} \mathrm{~S}$ gas in the sewer may be adsorbed in the thin film of water that usually covers the sewer walls and may be incompletely oxidized to sulphuric acid by bacteria (Hvitved-Jacobson, 2002; Tanaka et al., 2000). Bacteria in urban or industrial wastewater with favourable nutrient doses combined with facultative environments, i.e., space above the water causes the development of bacterial colonies. These bacterial colonies tend to lower the $\mathrm{pH}$ and oxidize $\mathrm{H}_{2} \mathrm{~S}$ to produce sulphuric acid, which causes corrosion. This sulphuric acid induced corrosion *Author for correspondence; E-mail: pcsir322@gmail.com can deteriorate cement and iron piping very quickly. To prevent the spread and development of the bacterial biofilm in cement and iron pipes, root cause of this issue need to be focussed.

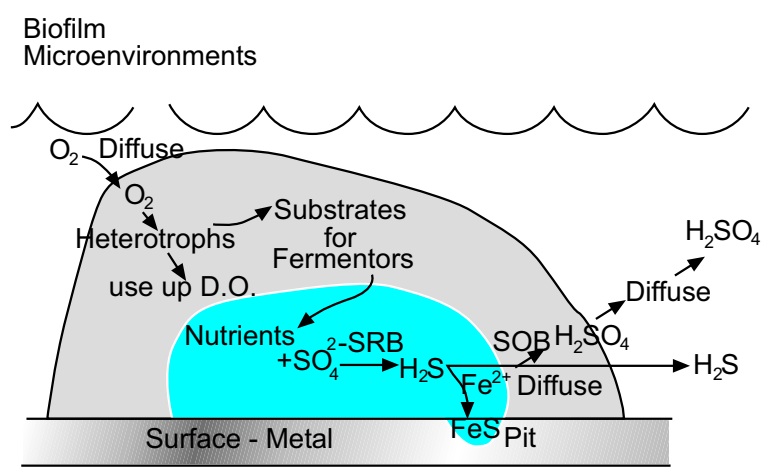

Bio film in collection system (Nielsen et al., 2005; HvitvedJacobson, 2002)

Generally the sulphide produced from anaerobic sulphate decreases biofilms covering the wetted sewer walls (Hvitved-Jacobson, 2002). The sulphides produced in the biofilms will diffuse the water phase and if dissolved oxygen is higher in concentration, the sulphide will be oxidized in the external parts of the biofilm (Kamp et al., 2006). Sulphide does not enter the water phase if dissolved oxygen concentration is above $1 \mathrm{~g} / \mathrm{L}$. Metal sulphides gathered in the biofilm can no longer be released (Nielsen et al., 2005 ; Hvitved-Jacobson, 2002). 
Corrosion and odor problems in sanitary sewers are due to high sulphate concentrations. Sulphide corrosion in sewers may be controlled by oxidation reduction potential in the sewage water, through addition of oxygen and other chemical oxidizers. Oxygen may be introduced as pure oxygen or as air into main sewers systems. Oxygen may also be injected to sewer. $\mathrm{H}_{2} \mathrm{O}_{2}$ provides residual oxidizer protection for up to one hour without pressurization. Chlorine gas, hypochlorite and $\mathrm{KMNO}_{4}$ are also powerful oxidizers. These chemicals are used for effective sulphide control in sewers (Hampton Roads Manual, 2011; Calf and Eddy, 2009; Hvitved-Jacobson, 2002). However, blend of two or more of these chemicals may be counterproductive for sulphide control. Chemical requirements for complete sulphide oxidation depend on $\mathrm{pH}$ of solution and temperature. Corrosion in sanitary sewers is caused by oxidation of $\mathrm{H}_{2} \mathrm{~S}$ to sulphuric acid in the environment above wastewater. The sulphide from wastewater is generally removed by different treatments such as aeration, chemical oxidation and $\mathrm{H}_{2} \mathrm{O}_{2}$ but these do not actually remove the sulphur/ sulphide molecules from the system. Because the reduction of sulphur into $\mathrm{H}_{2} \mathrm{~S}$ or oxidation to sulphuric acid causes odor and corrosion problem. The high toxicity associated with $\mathrm{H}_{2} \mathrm{~S}$ is due to its ability to bind iron centers in enzymes, which effectively stops cellular respiration and deprives essential organs of energy (Hampton Roads Manual, 2011). Corrosion of metal and concrete is a major issue associated with the generation and oxidation of $\mathrm{H}_{2} \mathrm{~S}$. The higher level of sulphuric acid that is produced as a result of oxidation of $\mathrm{H}_{2} \mathrm{~S}$, which lowers the $\mathrm{pH}$ and, contributes to the declining of concrete, and stimulates ferrous pipe corrosion (Marry, 2005; Kerry et al., 1989). The rate of concrete corrosion depends on the permeability of concrete and the amount of gaseous $\mathrm{H}_{2} \mathrm{~S}$ that is adsorbed to the moist sewer walls. Signs of prolonged exposure to mild acid attack include rust bleeding and cracking of the concrete (Davit et al., 1998).

$\mathrm{H}_{2} \mathrm{~S}$ is a result of the breakdown of organic substances by bacteria, typically insufficient $\mathrm{O}_{2}$ in environment such as municipal sewer system. Controlling this hazardous gas is one of the most challenging problems faced today. Anaerobic microorganisms must have a food to stay alive. Within this environment, the richest source of food for anaerobic bacteria is sulphate. When these sulphates are consumed by the anaerobic bacteria, $\mathrm{H}_{2} \mathrm{~S}$ is produced (Calf and Eddy, 2009). These sulphidecontaining pollutants will either be oxidized, or released
BIOFILM DEVELOPMENT ${ }^{7}$

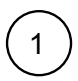

Organic substances absorb to surface

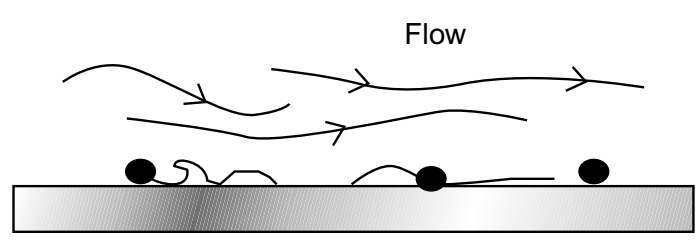

(2)

Primary colonisers attach planktonic cells

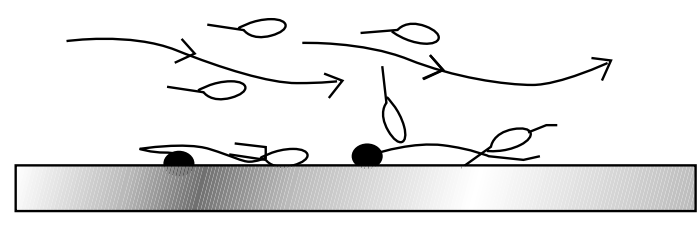

(3)

Formation of microcolonies

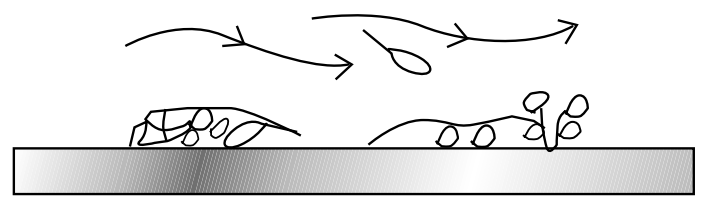

(4)

Succession of organisms \& increase diversity

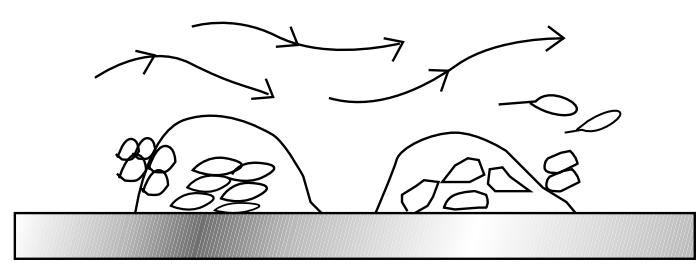

(5)

Mature structure concertia of organisms dispersion of cells

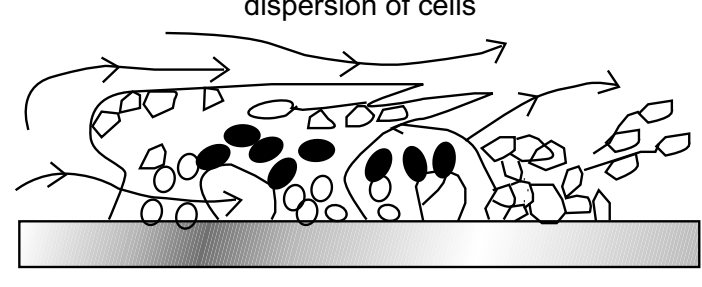

Bio film in collection system (Nielsen et al., 2005; HvitvedJacobson, 2002) 
into the sewer atmosphere (Zhu et al., 2009; Tanaka et al., 2000).

Oxidation by low cost oxidizers like ozone, chlorine, hydrogen peroxide and potassium permanganate was also used. This technique is easy to use and control. In case of high dose requirements, cost ineffectiveness for small amount of sulphide removal is a drawback of this method (Gholami et al., 2009). The aim of this study was to remove the sulphide from wastewater to control bacterial biofilms because corrosion damages the refrigerators and air conditioners in the study area.

\section{Materials and Methods}

Sampling. The sampling was made according to the standard methods for the examination of water and wastewater method No. 4500-F (Marry, 2005). The sampling was made in Lahore city, Pakistan from the main holes on the sewerage system laid down by the Water and Sanitation Agency (WASA), Lahore. The samples were collected in the 1.5 liter plastic bottles and preserved according to the standard methods and transported to the CEPS, PCSIR Laboratories complex, Lahore for chemical analysis.

\section{Sample handling and preservation}

i. Plastic bottles were used for sampling and it was carefully observed that the material suspension should not stick to container walls.

ii. Samples were preserved using zinc acetate and sodium hydroxide solution.

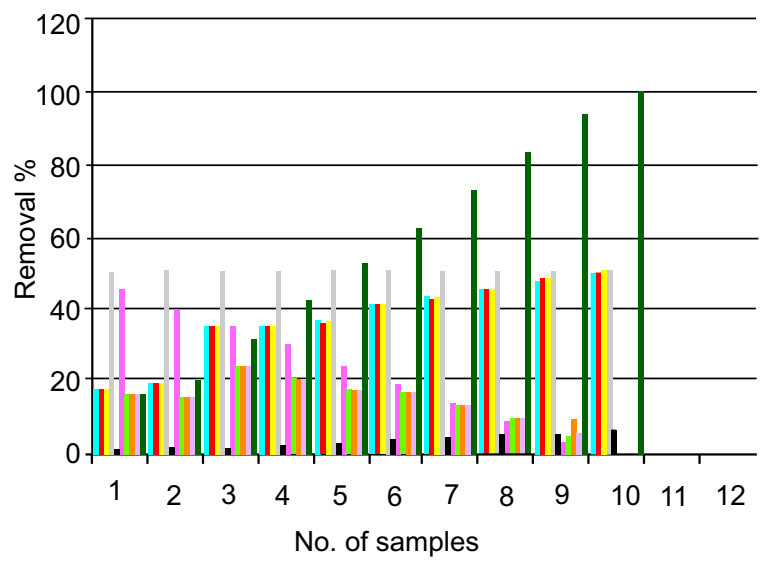

$\square R 1 \mathrm{mg} / \mathrm{L} \square \mathrm{R} 2 \mathrm{mg} / \mathrm{L} \square \mathrm{R} 3 \mathrm{mg} / \mathrm{L} \square$ Control 50 Dose Rate $\square \mathrm{RC} \mathrm{mg} / \mathrm{L} \square \mathrm{R} 4 \mathrm{mg} / \mathrm{L} \square \mathrm{R} 5 \mathrm{mg} / \mathrm{L} \square \mathrm{R} 6 \mathrm{mg} / \mathrm{L} \square \mathrm{R} \%$

Fig. 1. Sulphide removal using different oxygen dose rates (area A) iii. $0.2 \mathrm{~mL}$ of $2 \mathrm{~N}$ zinc acetate solution for $100 \mathrm{~mL}$ sample was used.

Volume of zinc acetate solution was increased if the sulphide concentration is expected to be greater than $64 \mathrm{mg} / \mathrm{L}$.

iv. The $\mathrm{pH}$ was adjusted at 9 using $\mathrm{NaOH}$ solution $5 \%$.

v. Bottles were filled completely and stoppered.

vi. $5 \mathrm{~mL}$ of potassium iodide solution was taken in a titration flask and $100 \mathrm{~mL}$ of water was added, then by pipette $20 \mathrm{~mL}$ of $0.025 \mathrm{~N}$ potassium iodate was added in the flask. Then $10 \mathrm{~mL}$ of diluted sulphuric acid was added and titration was done using $0.025 \mathrm{~N}$ thiosulphate. When solution becomes pale yellow few drops of starch solution were added in the flask and titration was done until the blue colour disappears (Marry, 2005; Kerry et al., 1989).

\section{Calculation}

One milliliter $0.025 \mathrm{~N}$ iodine solutions react with 0.4 $\mathrm{mg} \mathrm{S^{2- }}$

$$
\mathrm{mg} \mathrm{S}^{2-} / \mathrm{L}=\frac{[(\mathrm{A} \times \mathrm{B})-(\mathrm{C} \times \mathrm{D})] \times 16000}{\mathrm{~mL} \text { sample }}
$$

where:

$$
\begin{aligned}
& \mathrm{A}=\text { Iodine solution }(\mathrm{mL}) \\
& \mathrm{B}=\text { Normality of iodine solution } \\
& \mathrm{C}=\mathrm{Na}_{2} \mathrm{~S}_{2} \mathrm{O}_{3} \text { solution }(\mathrm{mL}) \\
& D=\text { Normality of } \mathrm{Na}_{2} \mathrm{~S}_{2} \mathrm{O}_{3} \text { solution }
\end{aligned}
$$

Samples were brought to room temperature $32{ }^{\circ} \mathrm{C}$ before analysis. Samples were analysed in replicate.

\section{Results and Discussion}

The results before and after treatment with $\mathrm{O}_{2}, \mathrm{KMNO}_{4}$ and $\mathrm{H}_{2} \mathrm{O}_{2}$ along with control samples of $50 \mathrm{~g}$ and 100 $\mathrm{g}$ are presented in Figs. 1-10. The treatment was made with $1.0 \mathrm{mg} / \mathrm{min}$ for samples and control, removal rate was $10.36 \%$. The concentration of $\mathrm{H}_{2} \mathrm{~S}$ before and after treatment was $18.3 \mathrm{mg} / \mathrm{L}$ and $16.47 \mathrm{mg} / \mathrm{L}$. The maximum dose of $5 \mathrm{mg} / \mathrm{L}$ of $\mathrm{O}_{2}$ was used for the treatment of sulphide removal from $50 \mathrm{mg} / \mathrm{L}$ to $3.01 \mathrm{mg} / \mathrm{L}$ removal percentage for control sample was $93.97 \%$ and for unknown samples $47.38 \mathrm{mg} / \mathrm{L}$ and at dose rate of 6 $\mathrm{mg} / \mathrm{L}$ removal was $100 \%$.

The results of sulphide removal before and after treatment with $\mathrm{O}_{2}$ as oxidizer for unknown and control samples are presented in Fig. 4 and 7 respectively, which are similar for removal percentage with dose rate of $1 \mathrm{~g}$ dose, removal of $\mathrm{H}_{2} \mathrm{~S}$ in controls were from 89.64 to $100 \mathrm{~g}$ with percentage removal $10.36 \%$ and in 
unknown samples at the similar dose rate results were 32.56 to $29.19 \mathrm{~g}$ with removal percentage $10.36 \%$. The reduction in sulphide values in controls and unknown samples were from 100 to 6.57 and 100 to $6.03 \mathrm{~g}, 60.98$ to $3.68 \mathrm{~g}$ and 62.27 to $3.75 \mathrm{~g}$ with $\mathrm{O}_{2}$ dose rate of $5 \mathrm{~g} / \mathrm{g}$ of $\mathrm{O}_{2}$.

In Figs. 2, 4 and 8 the treatment was given with $\mathrm{KMNO}_{4}$ to control and unknown samples, the removal in control and unknown samples at dose rate of $1 \mathrm{~g} / \mathrm{g}$ removal was $6.66 \%$ in both type of samples result of before and after treatment were $50 \mathrm{~g}$ to $46.67 \mathrm{~g}, 100 \mathrm{mg}$ to $93.34 \mathrm{~g}$ and unknown were 18.30 to $17.11,73.6$ to 68.7 and

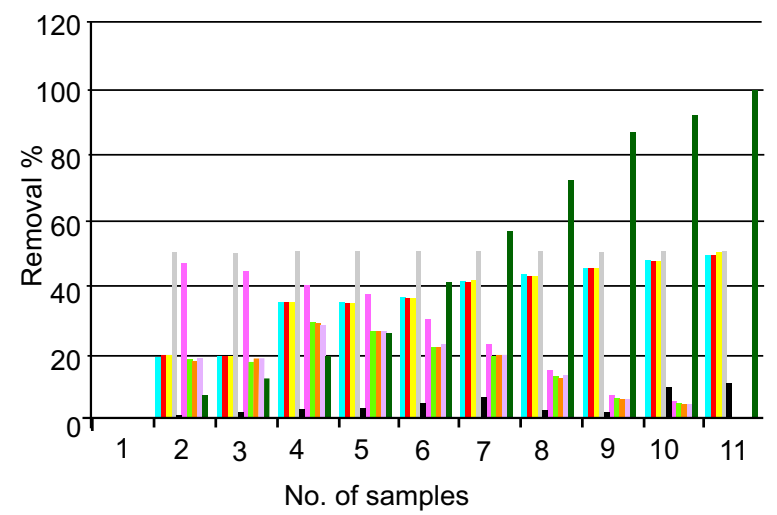

$\square \mathrm{R} 1 \mathrm{mg} / \mathrm{L} \square \mathrm{R} 2 \mathrm{mg} / \mathrm{L} \square \mathrm{R} 3 \mathrm{mg} / \mathrm{L} \square$ Control $50 \square$ Dose Rate $\square \mathrm{RC} \mathrm{mg} / \mathrm{L} \square \mathrm{R} 4 \mathrm{mg} / \mathrm{L} \square \mathrm{R} 5 \mathrm{mg} / \mathrm{L} \square \mathrm{R} 6 \mathrm{mg} / \mathrm{L} \square \mathrm{R} \%$

Fig. 2. Sulphide removal using different $\mathrm{KMNO}_{4}$ dose rates (area A)

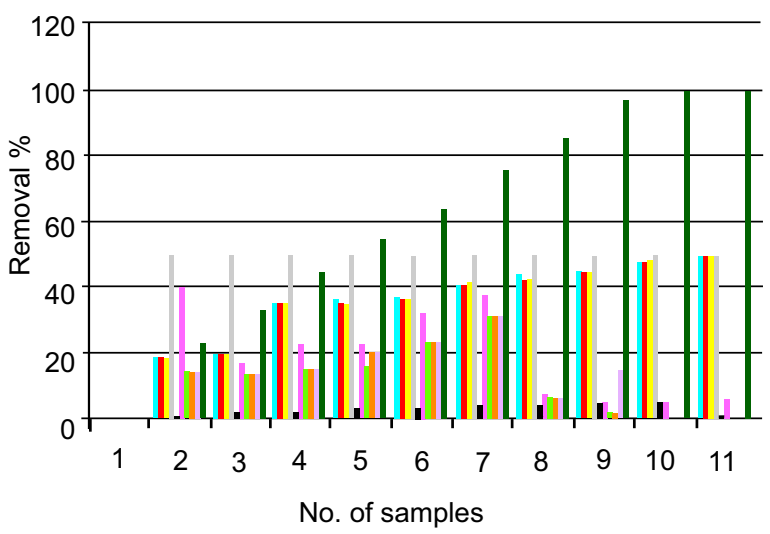

$\square \mathrm{R} 1 \mathrm{mg} / \mathrm{L} \square \mathrm{R} 2 \mathrm{mg} / \mathrm{L} \square \mathrm{R} 3 \mathrm{mg} / \mathrm{L} \square$ Control 50 Dose Rate $\square \mathrm{RC} \mathrm{mg} / \mathrm{L} \square \mathrm{R} 4 \mathrm{mg} / \mathrm{L} \square \mathrm{R} 5 \mathrm{mg} / \mathrm{L} \square \mathrm{R} 6 \mathrm{mg} / \mathrm{L} \square \mathrm{R} \%$

Fig. 3. Sulphide removal using different $\mathrm{H}_{2} \mathrm{O}_{2}$ dose rates (area $\mathrm{A})$
32.56 to $30.39 \mathrm{~g}$ and at dose rate of $9 \mathrm{~g}, 12 \mathrm{~g} 14 \mathrm{~g}$ results of controls and unknown samples before and after treatment were 50 to $4.03 \mathrm{mg}, 100$ to $8.05 \mathrm{~g}$ in unknown samples sulphide reduction was 47.82 to $3.82 \mathrm{~g}, 60.96$ to $4.91 \mathrm{~g}$ and $62.27 \mathrm{~g}$ to $5.01 \mathrm{~g}$ at $10.5 \mathrm{~g}$ dose rate. The sulphide removal was $100 \%$ in both categories at $\mathrm{O}_{2}$ dose of $14 \mathrm{~g} / \mathrm{g}$.

In Figs. 3, 6 and 9 control and unknown samples were treated with $\mathrm{H}_{2} \mathrm{O}_{2}$ at various dose rates, at dose rate of $1 \mathrm{~g}$ and 50 to $39.01 \mathrm{mg}, 21.99 \%, 100$ to $78.01 \mathrm{mg}$, $99.51 \%, 100$ to $0.49 \mathrm{mg}$, at dose rate of 5.5 removals was $100 \%$. In unknown samples results with similar

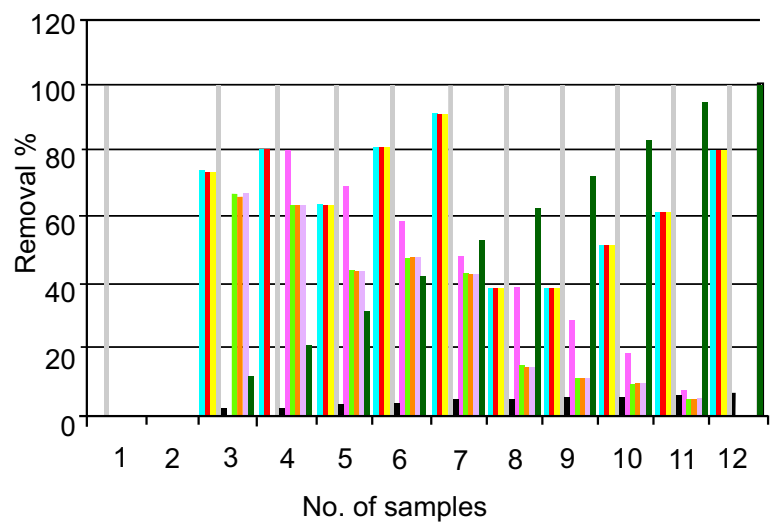

$\square \mathrm{R} 1 \mathrm{mg} / \mathrm{L} \square \mathrm{R} 2 \mathrm{mg} / \mathrm{L} \square \mathrm{R} 3 \mathrm{mg} / \mathrm{L} \square$ Control 50 Dose Rate $\square \mathrm{RC} \mathrm{mg} / \mathrm{L} \square \mathrm{R} 4 \mathrm{mg} / \mathrm{L} \square \mathrm{R} 5 \mathrm{mg} / \mathrm{L} \square \mathrm{R} 6 \mathrm{mg} / \mathrm{L} \square \mathrm{R} \%$

Fig. 4. Sulphide removal using different oxygen dose rates (area B)

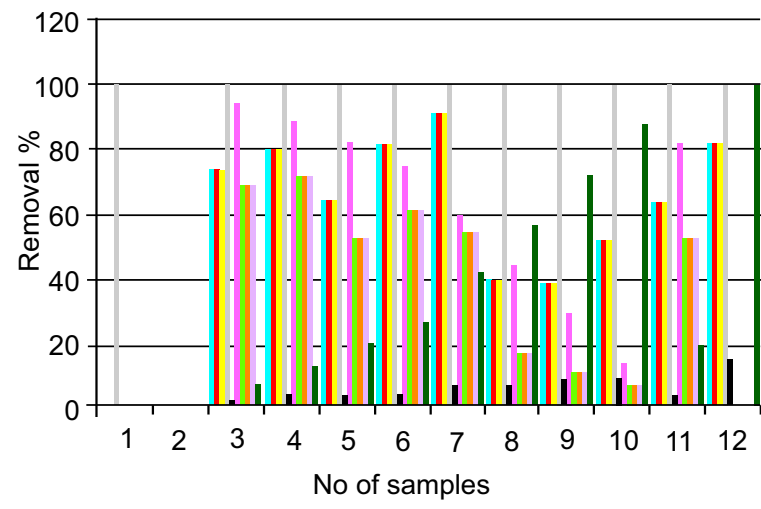

$\square \mathrm{R} 1 \mathrm{mg} / \mathrm{L} \square \mathrm{R} 2 \mathrm{mg} / \mathrm{L} \square \mathrm{R} 3 \mathrm{mg} / \mathrm{L} \square$ Control 50 Dose Rate $\square \mathrm{RC} \mathrm{mg} / \mathrm{L} \square \mathrm{R} 4 \mathrm{mg} / \mathrm{L} \square \mathrm{R} 5 \mathrm{mg} / \mathrm{L} \square \mathrm{R} 6 \mathrm{mg} / \mathrm{L} \square \mathrm{R} \%$

Fig. 5. Sulphide removal using different $\mathrm{KMNO}_{4}$ dose rates (area B) 
dose were 18.30 to $14.27 \mathrm{~g}, 60.96$. to $0.3 \mathrm{~g}$ and $62.27 \mathrm{~g}$ to $0.31 \mathrm{~g}$ and at $5.5 \mathrm{~g}$ removal was $100 \%$. The treatment of these known and unknown samples with different oxidizers such as $\mathrm{O}_{2}, \mathrm{KMNO}_{4}$ and $\mathrm{H}_{2} \mathrm{O}_{2}$ were tried and $\mathrm{H}_{2} \mathrm{O}_{2}$ was found most suitable for treatment with respect to dose rates, while $\mathrm{O}_{2}$ and $\mathrm{KMNO}_{4}$ were less effective for this treatment. The experimental results before and after treatment along with controls for oxidation of free sulphides with chlorine compounds, $\mathrm{KMNO}_{4}$ and $\mathrm{H}_{2} \mathrm{O}_{2}$ are presented in Figs. 1 to 9. Results presented in these figures show sulphides removal efficiencies after equilibrium was attained for various oxidizers to free sulphides percentages. For the tests with strong oxidizers

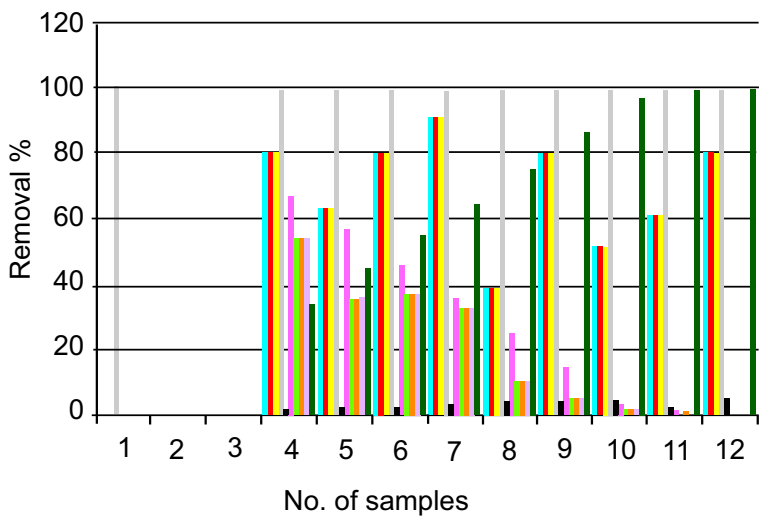

$\square \mathrm{R} 1 \mathrm{mg} / \mathrm{L} \square \mathrm{R} 2 \mathrm{mg} / \mathrm{L} \square \mathrm{R} 3 \mathrm{mg} / \mathrm{L} \square$ Control $50 \square$ Dose Rate $\square \mathrm{RC} \mathrm{mg} / \mathrm{L} \square \mathrm{R} 4 \mathrm{mg} / \mathrm{L} \square \mathrm{R} 5 \mathrm{mg} / \mathrm{L} \square \mathrm{R} 6 \mathrm{mg} / \mathrm{L} \square \mathrm{R} \%$

Fig. 6. Sulphide removal using different $\mathrm{H}_{2} \mathrm{O}_{2}$ dose rates (area B)

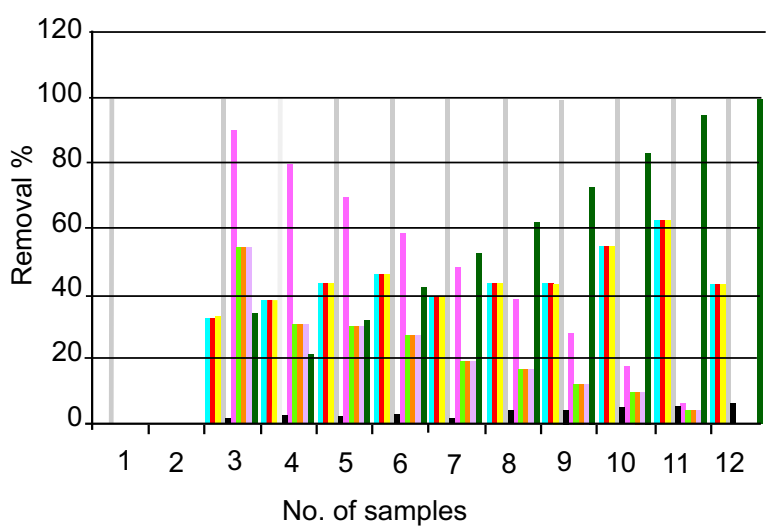

$\square R 1 \mathrm{mg} / \mathrm{L} \square \mathrm{R} 2 \mathrm{mg} / \mathrm{L} \square \mathrm{R} 3 \mathrm{mg} / \mathrm{L} \square$ Control 50 Dose Rate $\square \mathrm{RC} \mathrm{mg} / \mathrm{L} \square \mathrm{R} 4 \mathrm{mg} / \mathrm{L} \square \mathrm{R} 5 \mathrm{mg} / \mathrm{L} \square \mathrm{R} 6 \mathrm{mg} / \mathrm{L} \square \mathrm{R} \%$

Fig. 7. Sulphide removal using different oxygen dose rates (area $\mathrm{C}$ ) chlorine compounds and $\mathrm{KMNO}_{4}$, equilibrium conditions occurred five minutes after chemical addition. Oxidation of sulphides by $\mathrm{H}_{2} \mathrm{O}_{2}$ is a slower process requiring $30 \mathrm{~min}$ to reach equilibrium. Results presented in these figures correspond to values obtained at $5 \mathrm{~min}$ for strong oxidizers and contact time $30 \mathrm{~min}$ for the $\mathrm{H}_{2} \mathrm{O}_{2}$ tests. The wastewater used during the chlorine oxidation studies contained different concentrations of free sulphides before chemical addition. The figure shows that minimum dose required for complete sulphides removal in a typical wastewater sample is approx. $5.5 \mathrm{~g}$ of sulphides in solution. This experimentally determined demand is well within the theoretical limits.

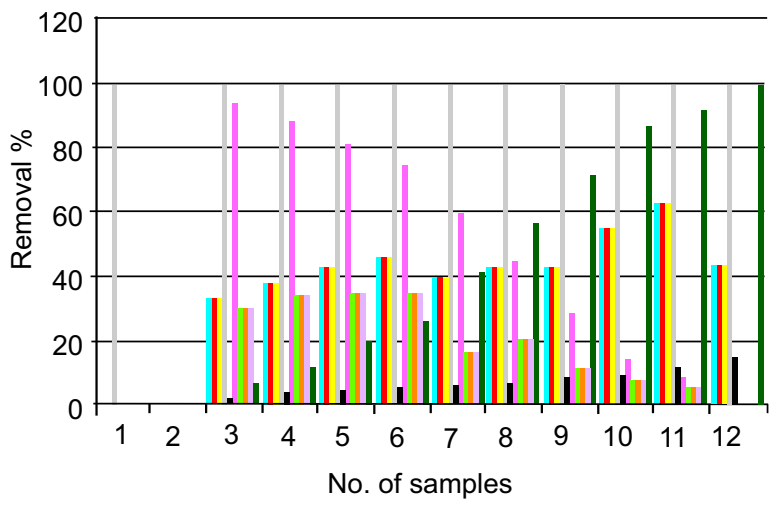

$\square R 1 \mathrm{mg} / \mathrm{L} \square \mathrm{R} 2 \mathrm{mg} / \mathrm{L} \square \mathrm{R} 3 \mathrm{mg} / \mathrm{L} \square$ Control $50 \square$ Dose Rate $\square \mathrm{RC} \mathrm{mg} / \mathrm{L} \square \mathrm{R} 4 \mathrm{mg} / \mathrm{L} \square \mathrm{R} 5 \mathrm{mg} / \mathrm{L} \square \mathrm{R} 6 \mathrm{mg} / \mathrm{L} \square \mathrm{R} \%$

Fig. 8. Sulphide removal using different $\mathrm{KMNO}_{4}$ dose rates (Area $\mathrm{C}$ )

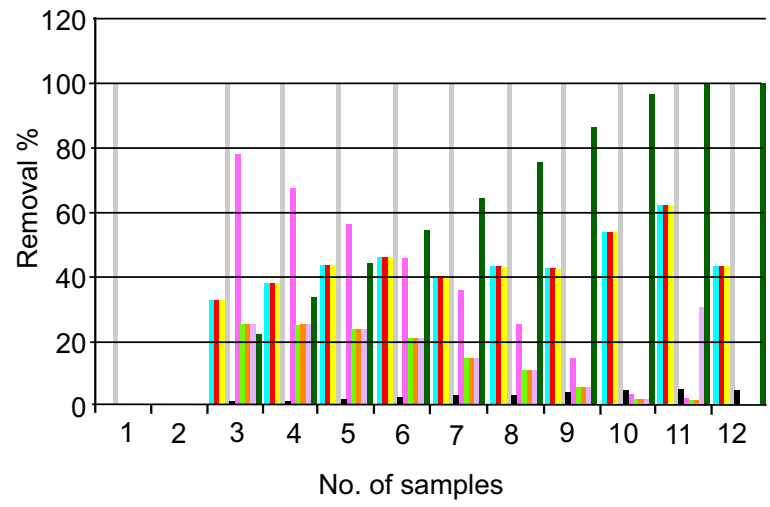

$\square \mathrm{R} 1 \mathrm{mg} / \mathrm{L} \square \mathrm{R} 2 \mathrm{mg} / \mathrm{L} \square \mathrm{R} 3 \mathrm{mg} / \mathrm{L} \square$ Control $50 \square$ Dose Rate $\square \mathrm{RC} \mathrm{mg} / \mathrm{L} \square \mathrm{R} 4 \mathrm{mg} / \mathrm{L} \square \mathrm{R} 5 \mathrm{mg} / \mathrm{L} \square \mathrm{R} 6 \mathrm{mg} / \mathrm{L} \square \mathrm{R} \%$

Fig. 9. Sulphide removal using different $\mathrm{H}_{2} \mathrm{O}_{2}$ dose rates (Area C) 
Figures 2, 4 and 8 also show results of the sulphide oxidation tests with potassium permanganate. The minimum potassium permanganate required for free sulphides removal was approximately $14 \mathrm{~g}$ of sulphides oxidized. This optimum dose ratio also falls within the theoretical limits. Measured sulphides concentration in the $\mathrm{H}_{2} \mathrm{O}_{2}$ tests depend on both the $\mathrm{H}_{2} \mathrm{O}_{2}, \mathrm{H}_{2} \mathrm{~S}$ ratio and the contact time. Free sulphides concentration for different tests (where $\mathrm{H}_{2} \mathrm{O}_{2}$ was used as oxidizing agents) are reported as functions of $\mathrm{H}_{2} \mathrm{O}_{2}: \mathrm{H}_{2} \mathrm{~S}$ ratio, even at the highest $\mathrm{H}_{2} \mathrm{O}_{2}: \mathrm{So}^{2-}$ rates. Free sulphides concentrations in the absence of oxidizers were also measured as a function of time.

Initial and final removal of sulphides concentration is presented in Figs 1 to 9.This trend occurs as long as $\mathrm{H}_{2} \mathrm{O}_{2}$ actively oxidizes $\mathrm{H}_{2} \mathrm{~S}$. This continues until the chemical is totally consumed. No additional sulphides removal is observed after this time. The residual effect of $\mathrm{H}_{2} \mathrm{O}_{2}$ is more marked at $\mathrm{H}_{2} \mathrm{O}_{2}: \mathrm{H}_{2} \mathrm{~S}$ ratios greater or equal to $5.5 \mathrm{~g} / \mathrm{g}$ where oxidation continues after $30 \mathrm{~min}$. On the other hand, at ratios lower than $1.2 \mathrm{~g} / \mathrm{g}$ the oxidation reaction stops in less than $5 \mathrm{~min}$. Termination of the reaction is possible because of the total consumption of the oxidizer.

The applicability of $\mathrm{H}_{2} \mathrm{O}_{2}$ is limited to field situations, where the oxidation kinetic exceeds the generation ratio; sulphides produced in sewers are faster than the rate at which they can be removed by $\mathrm{H}_{2} \mathrm{O}_{2}$. Oxidation may be protected by using other strong oxidizers. It is interesting to observe that $\mathrm{H}_{2} \mathrm{O}_{2}$ is completely depleted $\mathrm{H}_{2} \mathrm{O}_{2}$ : Sulphide ratios, lower than $5.5 \mathrm{~g} / \mathrm{g}$ of sulphides in less than $30 \mathrm{~min}$. Thus the minimum $\mathrm{H}_{2} \mathrm{O}_{2}$ required for the complete oxidation is approx. $5.5 \mathrm{~g}$ of pure $\mathrm{H}_{2} \mathrm{O}_{2}$ of free sulpdides. Equilibrium reactions between three supplied spices are represented by the following reactions (Marry, 2005).

Consequently $\mathrm{H}_{2} \mathrm{~S}$ is the main dissolved component at $\mathrm{pH}$ values below 7, while HS- predominates at $\mathrm{pH}$ values between neutrality and 14 . Sulphide induced order control in wastewater works may be accomplished by the use of various oxidizing agents which commonly include hypochlorite, chlorine and $\mathrm{KMNO}_{4}, \mathrm{H}_{2} \mathrm{O}_{2}$, and $\mathrm{O}_{2}$ (Hampton Roads Mannual, 2011; Calf and Eddy, 2009) end products and oxidizer demands are dependent on solution $\mathrm{pH}$ and redox potential (E-). Oxidizers increased the redox potential of the solution. Sulphides may be converted to more oxidizing forms such as sulphates and elemental sulphur by increasing solution of chemical oxidizer $\mathrm{O}_{2}$ unless excessive oxidizer doses are applied, oxidation of sulphides in the acidic range is incomplete, which results in elemental sulphur production. In the basic range sulphate is the end product of oxidation reaction. On the other hand complete oxidation of sulphide occurs at $\mathrm{pH}$ value above 7.5 resulting in the formation of $\mathrm{SO}_{4}$. Therefore, lower oxidizer doses are common in the acidic range because elemental sulphur possesses a lower oxidation potential then $\mathrm{SO}_{4}$. Therefore, oxidizer does typically increases with the increasing solution $\mathrm{pH}$. Therefore, hypochlorite salts and chlorine may be used for the oxidation of sulphides in well buffered waters where the $\mathrm{pH}$ of the solution will be very significant because of the introduction of the oxidizer. Addition of chlorine or hypochlorite to wastewater results in $\mathrm{OCl}$ production. This radical in turn reacts with $\mathrm{H}_{2} \mathrm{~S}$ to form the sulphur. On the stoichiometry reactions between 2.1 and $8.4 \mathrm{~g}$ of elemental chlorine are oxidized $1 \mathrm{~g}$ sulphides of $\mathrm{H}_{2} \mathrm{~S}$. The lower value for the chlorine demand is required in the acidic range. The larger demand value is required at $\mathrm{pH}$ values higher than 7.5 when sulphate is produced. Hypochlorous of ion requirement to fully complete the reactions are 1.5 and $6.1 \mathrm{~g}$ of sulphides oxidized corresponding chemical requirements of pure calcium hypochlorite vary from 2.1 and $8.4 \mathrm{~g}$ while those for pure sodium hypochloride are between 2.2 and $8.8 \mathrm{~g}$ of sulphides oxidized.

The oxidation rate of sulphide with $\mathrm{H}_{2} \mathrm{O}_{2}$ is relatively slow. 20 to $30 \mathrm{~min}$ contact times are normally required for a completed reaction. In the absence of bacteria $\mathrm{H}_{2} \mathrm{~S}$ reaction directly reacts $\mathrm{H}_{2} \mathrm{~S}$ as shown by the reaction $\mathrm{J}$ and $\mathrm{K}$. Reaction $\mathrm{J}$ occurs in the neutral and acidic range $(\mathrm{pH}<7.5)$. According to the stoichiometry of these reactions, between 1 to $4 \mathrm{~g}$ of pure $\mathrm{H}_{2} \mathrm{O}_{2}$ are required to oxidize $1 \mathrm{~g}$ of $\mathrm{H}_{2} \mathrm{~S}$.

$\mathrm{H}_{2} \mathrm{~S}+\mathrm{H}_{2} \mathrm{O}_{2}------2 \mathrm{H}_{2} \mathrm{O}+\mathrm{S}^{\circ}$ if $\mathrm{pH}<7.5$----------(A)

$\mathrm{H}_{2} \mathrm{~S}+4 \mathrm{H}_{2} \mathrm{O}_{2}----\mathrm{SO}_{4}^{2-}+4 \mathrm{HO}_{2}+2 \mathrm{H}+$ if $\mathrm{pH}>7.5$----(B)

The mechanism of oxidation of $\mathrm{H}_{2} \mathrm{~S}$ by $\mathrm{H}_{2} \mathrm{O}_{2}$ in wastewater is not well understood. Others suggest that direct oxidation of sulphides using $\mathrm{H}_{2} \mathrm{O}_{2}$ reaction $\mathrm{A}$ and $\mathrm{B}$ is unlikely in the presence of larger concentrations of bacterial catalase in wastewater. $\mathrm{H}_{2} \mathrm{O}_{2}$ first reacts with the bacterial catalase producing $\mathrm{O}_{2}$ and water (Nielsen et al., 2005; Hvitved-Jacobson, 2002). Sulphides in wastewater are oxidized by the dissolved $\mathrm{O}_{2}$ generated 
during gradual decomposition of $\mathrm{H}_{2} \mathrm{O}_{2}$ the stoichiometric requirement should be identical, regardless of the oxidation reaction path way. Therefore, reactions $A$ and $\mathrm{B}$ are also commonly accepted for sulphides oxidations in wastewater. $\mathrm{H}_{2} \mathrm{O}_{2}$ is manufactured as fluid in concentrations as high as $15 \%$ pure hydrogen per oxide has a specific gravity of $1.2 \mathrm{~cm}^{3} / \mathrm{g}$ at $20^{\circ} \mathrm{C}$. The stoichiometry requirement to satisfy reactions $\mathrm{A}$ and $\mathrm{B}$ are 1.7 and $6.7 \mathrm{~mL}$ of $50 \% \mathrm{H}_{2} \mathrm{O}_{2} / \mathrm{g}$ of $\mathrm{H}_{2} \mathrm{~S}$, respectively.

Oxidation of $\mathrm{H}_{2} \mathrm{~S}$ with chlorine, $\mathrm{KMNO}_{4}$ and $\mathrm{H}_{2} \mathrm{O}_{2}$ was conducted under controlled laboratory conditions. The $\mathrm{pH}$ of the wastewater samples used in the study varied between 7.2 and 7.5. Oxidation reactions were maintained at approximately $25^{\circ} \mathrm{C} \pm 1{ }^{\circ} \mathrm{C}$. Free sulphides were analyzed using standard method with the preliminary investigations chlorine compounds and $\mathrm{KMNO}_{4}$ reacted rapidly in dissolved sulphide in solution. Oxidation of sulphides with the strong oxidizers occurred in $5 \mathrm{~min}$ after chemical addition. On the other hand the kinetics of sulphides oxidation with the $\mathrm{H}_{2} \mathrm{O}_{2}$ was significantly slower. Two different experimental procedures were designed to evaluate the effectiveness of oxidizers. In the first experimental procedure sodium hypochlorite, commercial and in liquid form containing $7.5 \%$ elemental chlorine and $\mathrm{KMNO}_{4}$ industrial grade, $97 \%$ pure were used to prepare dilute stock solutions for the oxidation tests. Different volumes of stock solution were dispensed into replicate $300 \mathrm{~mL}$ bottles previously filled up to capacity. The bottles were carefully stoppered to evacuate the gas. Concentration of free sulphides was measured before tests 5 min after each oxidizer was added. Two small reactors were used in the second phase (Bowker, 1985; Waltrip and Snyder,

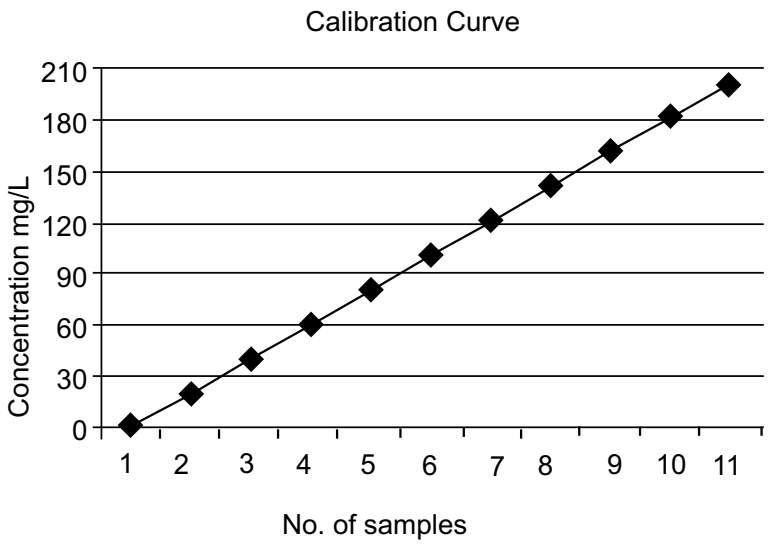

Fig 10. Calibration curve for sulphide
1985; Parthum, and Leffel, 1979; Dague, 1972). During the $\mathrm{H}_{2} \mathrm{O}_{2}$ tests shown in the figure the $\mathrm{DO}$ and $\mathrm{pH}$ of the solution were measured. Precision of $\mathrm{pH}$ and $\mathrm{DO}$ measurement was $0.01 \mathrm{pH}$ units and $0.1 \mathrm{mg} / \mathrm{L}$, respectively. DO and temperature of solution was measured by DO meter and thermometer.

\section{Conclusion}

Kinetics of sulphides oxidation with chlorine compounds and $\mathrm{KMNO}_{4}$ very rapidly attained in five minutes after addition of oxidizer. Oxidation of sulphides with $\mathrm{H}_{2} \mathrm{O}_{2}$ is a relatively slow process. This oxidation reaction proceeds as long as residual per oxide remains in solution. Minimum dose of oxidizer required to remove one g. of free sulphides are equal to 11.0, 6.0 and 5.5 $\mathrm{g}$ of $\mathrm{H}_{2} \mathrm{O}_{2}, \mathrm{O}_{2}$ and $\mathrm{KMNO}_{4}$, respectively. Because of the relatively slow reaction rate, $\mathrm{H}_{2} \mathrm{O}_{2}$ provides extended sulphides protection while $\mathrm{O}_{2}$ and $\mathrm{KMNO}_{4}$, removed sulphides rapidly without providing a residual protection. Effective sulphides control in sewers using $\mathrm{H}_{2} \mathrm{O}_{2}$ is limited to conditions where sulphides generation is relatively slower than the removal rates. Stronger oxidizers may be used in more adverse conditions. Thus $\mathrm{H}_{2} \mathrm{O}_{2}$ is recommended for the sulphide removal treatment.

\section{Acknowledgement}

We are thankful to WASA, Lahore for providing assistance and map of Lahore sewer system.

\section{References}

Bowker, R.P.1985. Odor and corrosion control in sanitary sewerage systems and treatment plants EPA. 625/I85/18.U. S. EPA, Cincinnati, Ohio, USA.

Calf, M., Eddy, 2009.Wastewater Engineering, Treatment and Reuse. 70 pp., $4^{\text {th }}$ edition Tata, Mc Graw-Hill Education Private Limited West Patel Nagar, New Delhi, India.

Dague, R. R. 1972. Fundamentals of odor control. Journal of Water Pollution Control Federation, 44: 583-594.

Davit, P., Applebee, M., Craiglacher, Bessie, J.1998. Low parts per billion determination of sulfide by colourimetric argentometry. Environmental Science \& Technology, 32: 1734.

Gholami, Z., Torabi, A.M., Gholami, F., Razavi, A.S.A. 2009. Reactive absorption of hydrogen sulphide in aqueous ferric sulfate solution. World Academy of Science, Engineering and Technology, 3: 01-24. 
Hampton Roads Sanitation District Coatings Manual. 2011. Appendix A: Basics on corrosion in wastewater collection and treatment system: Management, Operations, and Maintenance Program Revised July 2011.

Hvitved-Jacobson, T. 2002. Sewer Processes - Microbial and Chemical Process Engineering of Sewer Networks. CRC Press, Florida, USA.

Kamp, A., Stief, P., Schulz-Vogt, H. N. 2006. Anaerobic sulphide oxidation with nitrate by a freshwater Beggiatoa enrichment culture. Applied and Environmental Microbiology, 72: 4755-4760.

Kerry, L., Tusla, S., Maron, O., Woolsey, E., Okala, T., Frances, S,M., Okla, T ., Montgomery, A., Antonio,S ., Michael, T., Mcinerney, J., Okla, N. 1989. Microbial Control of $\mathrm{H}_{2} \mathrm{~S}$ Production by Sulphate Reduction Bacteria. Patent no. 4879240. USA Patents.

Maata, H.T., Hogendoornb, J.A., Versteeg, G.F. 2005. The removal of hydrogen sulfide from gas streams using an aqueous metal sulphate absorbent. Separation and Purification Technology, 43: 199-213.

Marry, A.H.F .2005. Standard Methods for Examination of Water \& Wastewater. $21^{\text {st }}$ edition, AWWA/ APHA. P.4 -170 to $4-176$.

Nielsen, A., Yongsiri, C., Hvitved-Jacobsen, T., Vollertsen, J. 2005. Simulation of sulphide buildup in wastewater and atmosphere of sewer networks.
Water Science and Technology, 52: 201-208.

Parthum, C.A., Leffel, R.E. 1979.Odor Control for Wastewater Facilities. Manual of Practice No.22, pp. 1-13, Water Pollution Control Federation Washington, D.C. USA.

Premkumar, R., Krishnamohan, N. 2013. Biological elimination of volatile hydrogen sulphide compounds in bio filters. International Journal of Chemical Technology Research, 5: 56-64.

Sunil, J.K., Jayant, P.K. 2014. Removal of cadmium from wastewater by groundnut shell adsorbentbatch and column studies. International Journal of Chemical Engineering Research, 6: 27-37.

Tanaka, N., Hvitved-Jacobsen, T., Horie, T. 2000. Transformations of carbon and sulfur wastewater components under aerobic-anaerobic transient conditions in sewer systems. Water Environment and Research, 72: 665-674.

Waltrip, G. D., Snyder, E. G. 1985. Elimination of odor at six major wastewater treatment plants. Journal of Water Pollution Control Federation, 50: $1027-$ 1032.

Zhu, H. T., Wen, X. H., Huang, X. 2009. Effect of ozone on membrane fouling in water and wastewater treatment: a research review. Huan jing ke xue Huanjing kexue/[bian ji, Zhongguo ke xue yuan huan jing ke xue wei yuan hui" Huan jing ke xue" bian ji wei yuan hui, 30: 302-312. 